\title{
Selective Catalytic Reduction of NO in Diesel Exhaust over Anodic Alumina Catalyst
}

\author{
Yu GUO*, Makoto SAKURAI*, Hideo KAMEYAMA*, \\ Akira MATSUYAMA** and Yasushi $\mathrm{KUDOH}^{* *}$
}

\author{
*Department of Chemical Engineering, Tokyo University of Agriculture and Technology (2-24-16, Naka- \\ cho, Koganei-shi, Tokyo 184-8588) \\ ${ }^{* *}$ Lead Industry Company Ltd. (13, Miwa-cho, Machida-shi, Tokyo 195-0054)
}

\begin{abstract}
A series of $\mathrm{Cu}-\mathrm{Mn}-\mathrm{Ce} / \mathrm{Al}_{2} \mathrm{O}_{3}$ anodic alumina catalysts synthesized using the multi-impregnation method were employed to investigate the selective reduction of $\mathrm{NO}$ with $\mathrm{C}_{3} \mathrm{H}_{6}$ in the presence of excess $\mathrm{O}_{2}$. The presence of $\mathrm{Cu}$ additive greatly promoted the low-temperature de- $\mathrm{NO}_{\mathrm{x}}$ activity. A moderate loading of copper gave the most promising $\mathrm{NO}_{\mathrm{x}}$ conversion. In contrast, no promotional effect on low-temperature de- $\mathrm{NO}_{\mathrm{x}}$ activity was found when Mn was added to the alumina support. Although the Mn-supported catalyst exhibited a higher activity for the oxidation of $\mathrm{NO}$ to $\mathrm{NO}_{2}$, the addition of $\mathrm{Mn}$ to the $\mathrm{Cu}-\mathrm{Ce} / \mathrm{Al}_{2} \mathrm{O}_{3}$ catalyst had no positive effect on $\mathrm{NO}_{x}$ reduction, due to the wasteful consumption of propene. The de- $\mathrm{NO}_{x}$ activity of the $\mathrm{Cu}-\mathrm{Ce} / \mathrm{Al}_{2} \mathrm{O}_{3}$ catalyst was maintained at a relatively high level, even in the presence of excess $\mathrm{SO}_{2}(500 \mathrm{ppm})$ and $\mathrm{H}_{2} \mathrm{O}(10 \mathrm{vol} \%)$. Furthermore, the presence of $\mathrm{SO}_{2}$ was observed to greatly promote $\mathrm{NO}_{x}$ reduction at $723 \mathrm{~K}$.
\end{abstract}

Key Words : Anodic Alumina Catalyst, Selective Catalytic Reduction, $\mathrm{NO}_{\mathrm{x}}$ Removal, Copper, Manganese

\section{Introduction}

The selective catalytic reduction of NO with hydrocarbons as reducing agents (SCR-HC of NO) has received much attention as a possible means of controlling the emissions from diesel vehicles in which engines operate under oxygen-rich conditions. Most of the reports published so far are related to zeolite catalysts such as Cu-ZSM-5, Fe-ZSM-5 and Pt/HZSM-5 ${ }^{1) 3)}$. Though zeolite-based catalysts have been reported to be highly active for the present reaction, their poor hydrothermal properties, diffusion limitations and narrow operating windows make them unsuitable from a practical point of view.

Metal-supported oxide catalysts have become the focus of recent research on the SCR-HC of NO due to their good thermal and hydrothermal stabilities and wide operating windows. $\gamma$-alumina appears to be one of the most active single metal oxides, and its de$\mathrm{NO}_{\mathrm{x}}$ activity can be further promoted by a wide range of metal and metal oxides such as $\mathrm{Pt}, \mathrm{Co}, \mathrm{Ag}$ and $\mathrm{Cu}$. $\mathrm{Cu}$ has been identified as one of the most promising elements for the SCR-HC of $\mathrm{NO}^{4) \sim 7)}$. In our present study, $\mathrm{Cu}$ was employed as the active metal and $\gamma$-alumina was used as the support. Mn was selected as a sub-metal to promote the conversion of NO to $\mathrm{NO}_{2}$, which is known to be one of the key steps ${ }^{8) \sim 12)}$.

In this study, anodization of aluminum was used to prepare the $\gamma$-alumina support. Porous alumina film can be formed on the surface of aluminum plate by anodization. Subsequently, hot water treatment and calcination transform the amorphous anodic alumina film into $\gamma$-alumina, and greatly increase its surface area $^{13)}$. The $\gamma$-alumina film prepared by this technology has a surface area $\left(\right.$ ca. $\left.140 \mathrm{~m}^{2} \cdot\left(\mathrm{g}-\mathrm{Al}_{2} \mathrm{O}_{3}\right)^{-1}\right)$ comparable to some commercial bead alumina catalysts. However, our previous research showed that a catalytic reactor prepared with the anodic alumina catalyst has a higher heat transfer coefficient than a traditional packed alumina catalytic reactor ${ }^{14)}$. In fact, the bead alumina catalyst has been rejected from catalyst support markets for auto exhaust control since the 1980 's, due to its poor thermal conductivity and high pressure drop. From a practical point of view, alumina must be highly dispersed on a carrier. The carrier should have a high loading area and favorable thermal conductivity, and allow a low pressure drop, as observed in the honeycomb-type ceramic carrier. In our anodic alumina catalyst, the alumina film comes from the surface of aluminum, and part of the aluminum (ca. $100 \mu \mathrm{m}$ ) remains in the interlayer of the catalyst. For this reason, an additional carrier is unnecessary in loading alumina. Comparison with commercial honeycomb-type ceramic catalysts (e.g. DASH-20 M supplied by Japan Engelhard Inc., surface area $\left.: 13 \mathrm{~m}^{2} \cdot\left(\mathrm{g}-\mathrm{Al}_{2} \mathrm{O}_{3}\right)^{-1}\right)$ shows that the anodic alumina catalyst has a sufficiently large surface area. Furthermore, since anodization is conducted in aqueous solution, an aluminum material with a complex structure such as honeycomb, mesh and serrated honeycomb can easily be prepared into an alumina support that allows a relatively low pressure drop $^{13) \sim 16)}$. Therefore, application of the anodic alumina support in auto exhaust control is a promis- 
ing area for further study.

In this paper, we report our results on the investigation into the activity of anodic alumina catalyst for the SCR-NO with $\mathrm{C}_{3} \mathrm{H}_{6}$.

\section{Experimental}

A commercial aluminum plate (JIS A 1050, thickness $0.3 \mathrm{~mm}$ ) was pre-treated in $20 \mathrm{wt} \%$ of sodium hydroxide for $3 \mathrm{~min}$ and $30 \mathrm{wt} \%$ of nitric acid for 1 min, and then rinsed with deionized water. The pre-treated aluminum plate was anodized in $4.0 \mathrm{wt} \%$ of oxalic acid for $16 \mathrm{~h}$ at an electric current density of $50 \mathrm{~A} \cdot \mathrm{m}^{-2}$ and a temperature of $293 \mathrm{~K}$, to form porous alumina film (ca. $100 \mu \mathrm{m}$ ). The plate was then washed, dried naturally, and calcined at $623 \mathrm{~K}$ to remove residual oxalic acid. Subsequently, hot water treatment (HWT) in deionized water at $353 \mathrm{~K}$ was conducted for $1 \mathrm{~h}$. The resulting plate was calcined in air at $773 \mathrm{~K}$ for $3 \mathrm{~h}$ to obtain the $\gamma$-alumina support.

$\mathrm{Cu}$ and $\mathrm{Mn}$ were selected as an active metal and a sub-metal, for the reasons discussed in section 1 . In addition, Ce was used to improve the thermal stability of the catalyst, especially at high temperatures $1^{17), 18}$. The co-impregnation method was employed to synthesize the $\mathrm{Cu}, \mathrm{Mn}$ and Ce supported alumina catalysts. In this case, the anodic $\gamma$-alumina support was impregnated by using an aqueous solution containing the required amounts of $\mathrm{Cu}\left(\mathrm{NO}_{3}\right)_{2} \cdot 3 \mathrm{H}_{2} \mathrm{O}, \mathrm{Mn}\left(\mathrm{NO}_{3}\right)_{2} \cdot 6$ $\mathrm{H}_{2} \mathrm{O}$ and $\mathrm{Ce}\left(\mathrm{NO}_{3}\right)_{3} \cdot 6 \mathrm{H}_{2} \mathrm{O}$, for $1 \mathrm{~h}$ under ambient conditions. The resulting plate was then dried naturally for $4 \mathrm{~h}$, and calcined in air at $773 \mathrm{~K}$ for $3 \mathrm{~h}$. The impregnation and the calcination were repeated 5 times, to enhance metal loading. During impregnation, $\mathrm{pH}$ adjustment of the impregnation solution was not carried out, and the aqueous solution was used directly to load the metals.

BET specific surface area and pore radius were measured by a nitrogen adsorption method (COULTER SA 3100). X-ray powder diffraction (XRD) analyses were performed on a SHIMADZU
XRD-6000, using $\mathrm{Cu} \mathrm{K} \alpha$ radiation. The metal contents were measured by atomic absorption spectrometry (SHIMADZU AA-680), and they are reported in this paper based on the apparent surface area of the catalyst (both sides of the plate-type catalyst, i.e. $\mathrm{g} \cdot \mathrm{m}^{-2}$ ). However, it should be noted that measurement of Ce loading using this technique is difficult, due to the relatively low Ce content, so Ce content is not given. Unless otherwise stated, 0.1 $\mathrm{mol} \cdot \mathrm{L}^{-1} \mathrm{Ce}$ was simultaneously added into the impregnation solution. Hereafter, the synthesized catalysts are referred to as $\mathrm{Cu}(x)-\mathrm{Ce}(0.1) / \mathrm{Al}_{2} \mathrm{O}_{3}, \mathrm{Mn}(y)-\mathrm{Ce}$ $(0.1) / \mathrm{Al}_{2} \mathrm{O}_{3}$ and $\mathrm{Cu}(x)-\mathrm{Mn}(y)-\mathrm{Ce}(0.1) / \mathrm{Al}_{2} \mathrm{O}_{3}$, where $x$ and $y$ are the metal-ion concentrations $\left(\mathrm{mol} \cdot \mathrm{L}^{-1}\right)$ of $\mathrm{Cu}$ and $\mathrm{Mn}$ in the impregnation solution, respectively.

A plug flow integrated reactor (i.d. $15 \mathrm{~mm}$ ) was used to test the de- $\mathrm{NO}_{\mathrm{x}}$ activity of each synthesized catalyst. The plate-type catalyst was cut into small pieces (ca. $5 \mathrm{~mm}^{2}$ ) and packed in the reactor, using quartz sand for dilution with a loading density of 0.4 $\mathrm{cm}^{2}$-catalyst $\cdot(\mathrm{g} \text {-quartz sand })^{-1}$. Both inlet and outlet stream mixtures were analyzed. Gas chromatographs were used to analyze $\mathrm{C}_{3} \mathrm{H}_{6}$ (FID), $\mathrm{O}_{2}, \mathrm{~N}_{2}$ and $\mathrm{CO}(\mathrm{TCD})$. $\mathrm{NO}_{\mathrm{x}}\left(\mathrm{NO}\right.$ and $\left.\mathrm{NO}_{2}\right)$ was measured with a chemiluminescent $\mathrm{NO}_{x}$ analyzer (HORIBA PG-235 gas analyzer). An infrared gas analyzer (SHIMADZU CGT-7000) was used to measure the $\mathrm{C}_{2}$ formed. A GC-MS (SHIMADZU GCMASS-QP 5050) equipped with a GS-Q column was utilized to analyze the production of $\mathrm{N}_{2} \mathrm{O}$. The amount of $\mathrm{SO}_{2}$ was measured using an infrared $\mathrm{SO}_{2}$ gas analyzer (SHIMADZU SOA-7000). A micro piston pump was used to introduce $\mathrm{H}_{2} \mathrm{O}$ into a vaporizer, and the amount of added $\mathrm{H}_{2} \mathrm{O}$ was measured by a balance. The reaction feedstream was prepared by mixing certified analyzed model gases (supplied by TOEI CHEM.), with helium as the carrier gas. The total gas flow rate was set at $9.0 \mathrm{~L} \cdot \mathrm{h}^{-1}\left(\mathrm{~F} / \mathrm{W}=37.5 \mathrm{~L} \cdot(\mathrm{g} \text {-catalyst })^{-1} \cdot \mathrm{h}^{-1}\right)$.

The results obtained were evaluated in terms of $\mathrm{NO}_{\mathrm{x}}$ conversion, $\mathrm{C}_{3} \mathrm{H}_{6}$ conversion, $\mathrm{N}_{2}$ selectivity and $\mathrm{CO}$

Table 1 Preparation conditions and characteristics of the anodic alumina catalysts.

\begin{tabular}{|c|c|c|c|c|c|}
\hline \multicolumn{2}{|c|}{$\begin{array}{c}\text { Concentrarion of } \\
\text { metal-ion }\end{array}$} & \multicolumn{2}{|c|}{ Metal loading } & \multirow{2}{*}{$\begin{array}{c}\text { BET } \\
\text { surface } \\
\text { area } \\
{\left[\mathrm{m}^{2 \cdot}\left(\mathrm{g}-\mathrm{Al}_{2} \mathrm{O}_{3}\right)^{-1}\right]}\end{array}$} & \multirow{2}{*}{$\begin{array}{c}\text { Pore } \\
\text { radius } \\
{[\mathrm{nm}]}\end{array}$} \\
\hline $\begin{array}{c}\mathrm{Cu} \\
{\left[\mathrm{mol} \cdot \mathrm{L}^{-1}\right]}\end{array}$ & $\begin{array}{c}\mathrm{Mn} \\
{\left[\mathrm{mol} \cdot \mathrm{L}^{-1}\right]}\end{array}$ & $\begin{array}{c}\mathrm{Cu} \\
{\left[\mathrm{g} \cdot \mathrm{m}^{-2}\right]}\end{array}$ & $\begin{array}{c}\mathrm{Mn} \\
{\left[\mathrm{g} \cdot \mathrm{m}^{-2}\right]}\end{array}$ & & \\
\hline- & - & - & - & 138.7 & 2.88 \\
\hline 0.017 & - & 4.84 & - & 90.1 & 4.11 \\
\hline 0.033 & - & 7.68 & - & 89.3 & 4.22 \\
\hline 0.067 & - & 8.90 & - & 97.8 & 4.42 \\
\hline 0.133 & - & 10.7 & - & 97.3 & 4.39 \\
\hline 0.267 & - & 12.1 & - & 96.1 & 4.35 \\
\hline 0.400 & - & 12.6 & - & 95.9 & 4.30 \\
\hline- & 0.25 & - & 3.23 & 76.5 & 3.54 \\
\hline- & 0.50 & - & 6.41 & 78.3 & 3.69 \\
\hline- & 1.00 & - & 7.02 & 84.7 & 3.74 \\
\hline- & 1.50 & - & 7.05 & 81.5 & 3.71 \\
\hline- & 2.00 & - & 6.99 & 82.7 & 3.80 \\
\hline 0.033 & 0.10 & 7.61 & 0.97 & 83.2 & 3.64 \\
\hline 0.033 & 0.50 & 7.54 & 5.51 & 79.9 & 3.68 \\
\hline
\end{tabular}


selectivity. $\mathrm{N}_{2}$ selectivity was defined as $: 2 \times$ $\mathrm{N}_{2}$ produced $/\left(\mathrm{NO}_{\mathrm{x} \text { inlet }}-\mathrm{NO}_{\mathrm{x} \text { outlet }}\right) \times 100 \%$, and $\mathrm{CO}$ selectivity was expressed as : $\mathrm{CO}_{\text {produced }} /\left(3 \times\left(\mathrm{C}_{3} \mathrm{H}_{6}\right.\right.$ inlet $\mathrm{C}_{3} \mathrm{H}_{6}$ outlet $\left.)\right) \times 100 \%\left(\mathrm{NO}_{x}, \mathrm{~N}_{2}, \mathrm{CO}\right.$ and $\mathrm{C}_{3} \mathrm{H}_{6}:$ molar flow rate).

\section{Results and Discussion}

Using the anodic alumina support, a series of $\mathrm{Cu}$ $\mathrm{Mn}-\mathrm{Ce} / \mathrm{Al}_{2} \mathrm{O}_{3}$ catalysts were prepared by varying the $\mathrm{Cu}$ and $\mathrm{Mn}$ concentrations in the impregnation solution. The characteristics of these catalysts are presented in Table 1. An anodic alumina support used as a reference catalyst is also listed in Table 1. Comparison of the alumina support with the metalsupported alumina catalysts shows a decrease in BET specific surface area and an increase in pore radius. Dissolution of the alumina film in the acidic impregnation solution is considered to be responsible for this change. $\mathrm{Cu}$ and $\mathrm{Mn}$ loadings are gradually enhanced as the metal-ion concentrations are increased. How- ever, a limitation to metal loading is observed when the impregnation concentration exceeds a specific value, which is determined by the adsorption equilibrium of metal ions and the diffusion resistance in micropores under the present conditions. Another possible reason for this could be the dynamic balance between the metal adsorption and the dissolution of the alumina film.

Figure 1 shows the catalytic activities of different alumina catalysts for (a) $\mathrm{NO}_{\mathrm{x}}$ conversion, (b) $\mathrm{C}_{3} \mathrm{H}_{6}$ conversion, (c) $\mathrm{N}_{2}$ selectivity and (d) $\mathrm{CO}$ selectivity. It should be noted that the catalytic activity values associated with a metal loading of zero were achieved over the alumina support. In Fig. 1(a), the alumina support gives maximal $\mathrm{NO}_{\mathrm{x}}$ conversion at $823 \mathrm{~K}$. Nevertheless, compared with the alumina support, the $\mathrm{Cu}-\mathrm{Ce} / \mathrm{Al}_{2} \mathrm{O}_{3}$ catalyst exhibits a higher de- $\mathrm{NO}_{x}$ activity when the temperature is less than $673 \mathrm{~K}$. For example, at $623 \mathrm{~K}$, the $4.84 \mathrm{~g} \cdot \mathrm{m}^{-2} \mathrm{Cu}$ additive greatly increases $\mathrm{NO}_{\mathrm{x}}$ conversion, from $8 \%$ to $28 \%$. This
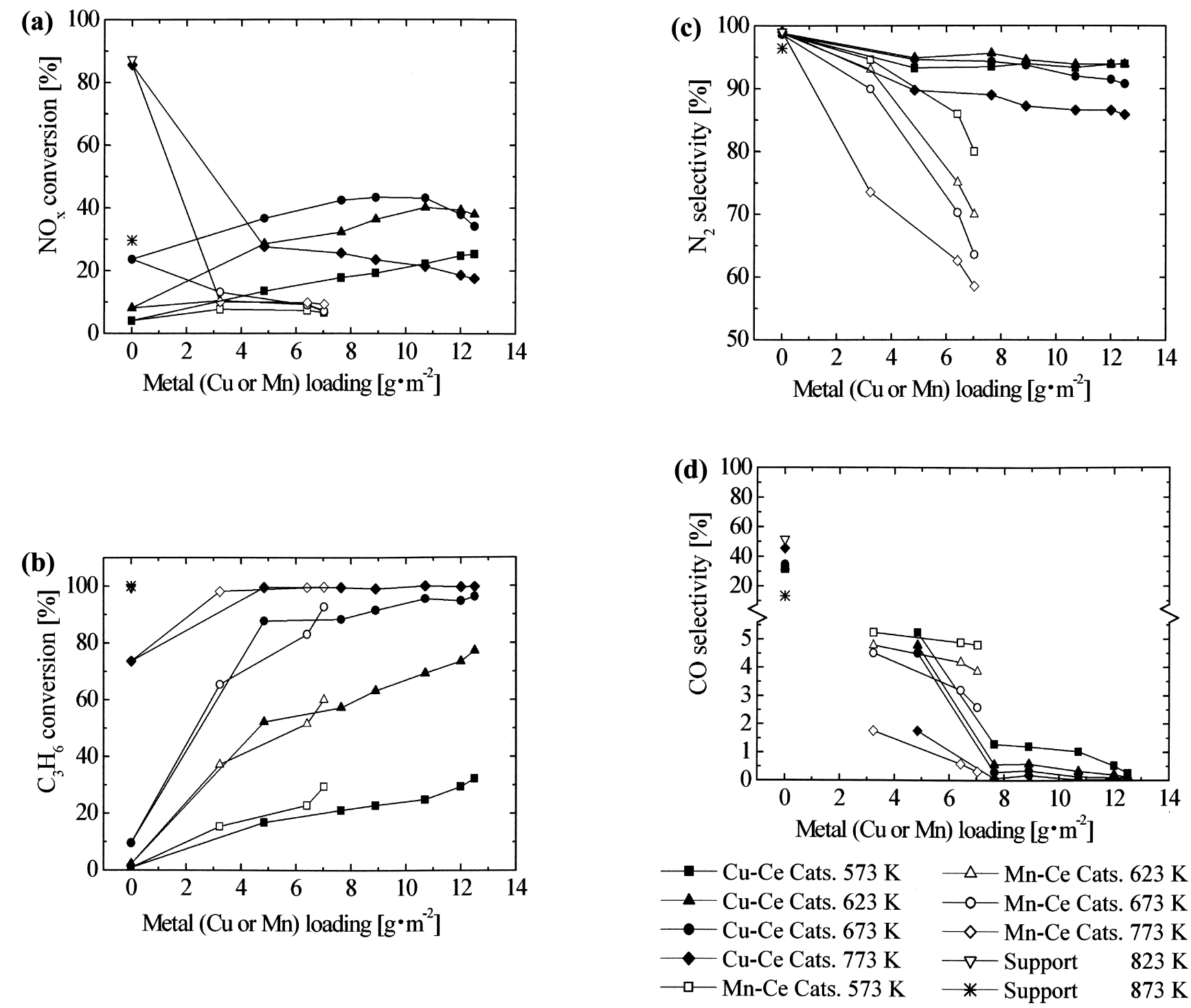

Fig. 1 Catalytic activities of $\mathrm{Cu}-\mathrm{Ce} / \mathrm{Al}_{2} \mathrm{O}_{3}$ and $\mathrm{Mn}-\mathrm{Ce} / \mathrm{Al}_{2} \mathrm{O}_{3}$ as a function of metal ( $\mathrm{Cu}$ or $\mathrm{Mn}$ ) loading.

(a) $\mathrm{NO}_{\mathrm{x}}$ conversion; (b) $\mathrm{C}_{3} \mathrm{H}_{6}$ conversion ; (c) $\mathrm{N}_{2}$ selectivity ; (d) CO selectivity $\left(\mathrm{O}_{2} 15.0\right.$ vol\%, $\mathrm{C}_{3} \mathrm{H}_{6} 0.5$ vol\%, $\mathrm{NO}$ $1000 \mathrm{ppm}$ ) 
proves that $\mathrm{Cu}$ exerts a significant influence on the SCR-HC of NO. In addition, the addition of $\mathrm{Cu}$ is observed to have different effects on reducing $\mathrm{NO}_{\mathrm{x}}$, depending on temperature. At low temperatures $(573 \mathrm{~K}$ and $623 \mathrm{~K}), \mathrm{NO}_{\mathrm{x}}$ conversion always increases with an increased $\mathrm{Cu}$ loading. In contrast, at $773 \mathrm{~K}$, an increase in copper loading gradually decreases $\mathrm{NO}_{\mathrm{x}}$ conversion. At an intermediate temperature of $673 \mathrm{~K}$, $\mathrm{NO}_{\mathrm{x}}$ conversion is firstly promoted from $36 \%$ to $43 \%$ with an increase in copper loading from 4.8 to $10.7 \mathrm{~g} \cdot$ $\mathrm{m}^{-2}$, but further increases in copper loading reduce $\mathrm{NO}_{\mathrm{x}}$ conversion. This result at $673 \mathrm{~K}$ indicates that a moderate $\mathrm{Cu}$ loading gives the most promising $\mathrm{NO}_{\mathrm{x}}$ conversion. This bell-type plot at $673 \mathrm{~K}$ is in agreement with the work reported by Amin et al. ${ }^{6)}$ and Shimizu et al. ${ }^{19)}$, which demonstrated that intermediate loading of an active metal always gave the most promising result, regardless of the catalyst support. In the case of the $\mathrm{Mn}-\mathrm{Ce} / \mathrm{Al}_{2} \mathrm{O}_{3}$ catalyst, however, the promotional effect on low-temperature de- $\mathrm{NO}_{\mathrm{x}}$ activity is not found.

As shown in Fig. 1(b), the presence of metal additives greatly improves the propene oxidation. In the case of the $\mathrm{Cu}-\mathrm{Ce} / \mathrm{Al}_{2} \mathrm{O}_{3}$ catalyst, comparison of Fig. 1 (a) with Fig. 1(b) shows that the $\mathrm{NO}_{\mathrm{x}}$ reduction is coincident with the $\mathrm{C}_{3} \mathrm{H}_{6}$ oxidation. That is, $\mathrm{NO}_{x}$ conversion is increased as propene is effectively oxidized (or activated), but once $\mathrm{C}_{3} \mathrm{H}_{6}$ conversion approaches $100 \%, \mathrm{NO}_{\mathrm{x}}$ reduction is depressed. At low temperatures, propene activation improves with increasing $\mathrm{Cu}$ loading, which is one main reason for the increase in $\mathrm{NO}_{\mathrm{x}}$ conversion. On the other hand, at high temperatures, an increase in $\mathrm{Cu}$ loading overly accelerates propene oxidation by oxygen rather than $\mathrm{NO}_{x}$, which results in a lack of propene available for $\mathrm{NO}_{\mathrm{x}}$ reduction.

The formation of a small amount of $\mathrm{N}_{2} \mathrm{O}$ accompanying the $\mathrm{NO}_{\mathrm{x}}$ reduction was detected, which makes $\mathrm{N}_{2}$ selectivity less than $100 \%$ (Fig. 1 (c)). $\mathrm{N}_{2}$ selectivity gradually decreases with increasing $\mathrm{Cu}$ (or $\mathrm{Mn}$ ) loading. In comparison with $\mathrm{Mn}-\mathrm{Ce} / \mathrm{Al}_{2} \mathrm{O}_{3}, \mathrm{Cu}-$ $\mathrm{Ce} / \mathrm{Al}_{2} \mathrm{O}_{3}$ exhibits promising $\mathrm{N}_{2}$ selectivity.

$\mathrm{CO}$ selectivity is presented in Fig. 1(d). The undesirable production of $\mathrm{CO}$, as a by-product of the partial oxidation of propene, obviously decreases with increasing metal loading. CO production is almost negligible, especially over the $\mathrm{Cu}-\mathrm{Ce} / \mathrm{Al}_{2} \mathrm{O}_{3}$ catalyst. Although the alumina support exhibits maximal $\mathrm{NO}_{\mathrm{x}}$ conversion at $823 \mathrm{~K}$, excess production of $\mathrm{CO}$ is observed simultaneously. The higher optimal temperature $(823 \mathrm{~K})$ and excess production of $\mathrm{CO}$ are two major disadvantages that limit the application of the alumina support as a denitration catalyst. In addition, they indicate that the poor activation of propene by $\mathrm{O}_{2}\left(\right.$ or $\left.\mathrm{NO}_{\mathrm{x}}\right)$, which is known to be one of the key steps of the SCR-HC of $\mathrm{NO}^{8) \sim 10)}$, is responsible for the low activity of the alumina support at low temperatures.

Although $\mathrm{Mn}-\mathrm{Ce} / \mathrm{Al}_{2} \mathrm{O}_{3}$ exhibits poor de- $\mathrm{NO}_{x}$ activity at any temperature (Fig. 1(a)), the Mn additive un- doubtedly improves propene oxidation (Fig.1(b)). This result indicates that a Mn-supported catalyst has favorable propene oxidation ability, but insufficient selectivity for $\mathrm{NO}_{\mathrm{x}}$ reduction.

In regard to the low-temperature de- $\mathrm{NO}_{\mathrm{x}}$ activity, the effect of a metal additive on the oxidation of NO to $\mathrm{NO}_{2}$ must be taken into account. The beneficial effect of using $\mathrm{NO}_{2}$ instead of $\mathrm{NO}$ as a starting $\mathrm{NO}_{x}$ molecule has already been extensively reported for the SCR-HC over metal-promoted $\gamma$-alumina catalysts $^{8) \sim 10), 20)}$. Figure 2 shows the activities of different alumina catalysts for the oxidation of NO to $\mathrm{NO}_{2}$ (without any reducing agent). The dotted line represents the thermodynamic limitation of $\mathrm{NO}_{2}$ yield associated with the following reaction:

$$
2 \mathrm{NO}+\mathrm{O}_{2} \Leftrightarrow 2 \mathrm{NO}_{2}
$$

No product other than $\mathrm{NO}_{2}$ was observed in the outlet stream. In a blank experiment, a $\mathrm{NO}_{2}$ yield of $6 \%$ was detected due to NO oxidation in the line pipes. Compared with the result for the blank experiment, the similar $\mathrm{NO}_{2}$ yield achieved over the alumina support shows that the support has a low reactivity for NO oxidation. The addition of $\mathrm{Cu}$ substantially enhances $\mathrm{NO}_{2}$ yield, and this promotional effect becomes more intense as the $\mathrm{Cu}$ loading increases. Accordingly, at low temperatures, the presence of $\mathrm{Cu}$ is considered to promote both the propene activation and the NO oxidation. At high temperatures, however, $\mathrm{NO}_{2}$ yield is not further increased by a higher $\mathrm{Cu}$ loading, due to the equilibrium limitation. Moreover, the oxidation of $\mathrm{C}_{3} \mathrm{H}_{6}$ by $\mathrm{O}_{2}$ increasingly prevails over the $\mathrm{C}_{3} \mathrm{H}_{6}+\mathrm{NO}_{\mathrm{x}}$ reaction with increasing $\mathrm{Cu}$ loading, and decreases $\mathrm{NO}_{\mathrm{x}}$ conversion. In Fig. 2, Mn-Ce/ $\mathrm{Al}_{2} \mathrm{O}_{3}$ shows a strong reactivity for the oxidation of $\mathrm{NO}$ to $\mathrm{NO}_{2}$, and this oxidation ability is superior to that of $\mathrm{Cu}-\mathrm{Ce} / \mathrm{Al}_{2} \mathrm{O}_{3}$. For this reason, we added $\mathrm{Mn}$ to $\mathrm{Cu}-$

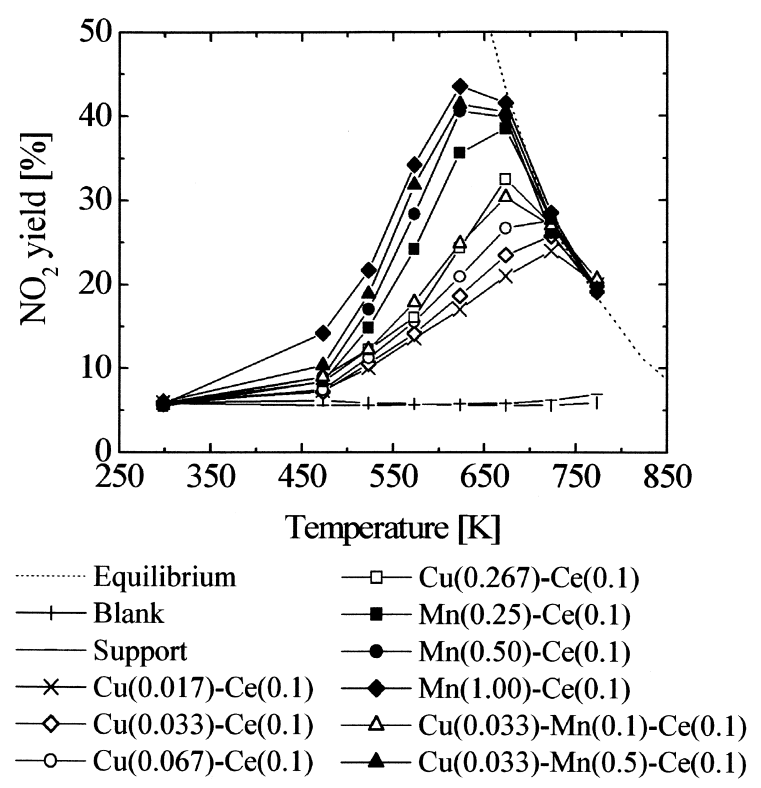

Fig. 2 Oxidation of $\mathrm{NO}$ to $\mathrm{NO}_{2}$ achieved over different catalysts.

$\left(\mathrm{O}_{2} 5.0 \mathrm{vol} \%\right.$, NO $\left.1000 \mathrm{ppm}\right)$ 
$\mathrm{Ce} / \mathrm{Al}_{2} \mathrm{O}_{3}$ to improve the $\mathrm{NO}$ oxidation. The characteristics of the $\mathrm{Cu}-\mathrm{Mn}-\mathrm{Ce} / \mathrm{Al}_{2} \mathrm{O}_{3}$ catalysts are also presented in Table 1. As shown in Fig. 2, the addition of $\mathrm{Mn}$ to $\mathrm{Cu}-\mathrm{Ce} / \mathrm{Al}_{2} \mathrm{O}_{3}$ significantly improves the $\mathrm{NO}$ oxidation activity of $\mathrm{Cu}-\mathrm{Ce} / \mathrm{Al}_{2} \mathrm{O}_{3}$.

Figure 3 shows (a) $\mathrm{NO}_{\mathrm{x}}$ conversion, and (b) $\mathrm{C}_{3} \mathrm{H}_{6}$ conversion achieved over $\mathrm{Mn}(0.5)-\mathrm{Ce}(0.1) / \mathrm{Al}_{2} \mathrm{O}_{3}, \mathrm{Cu}$ $(0.033)-\mathrm{Ce}(0.1) / \mathrm{Al}_{2} \mathrm{O}_{3}$ and $\mathrm{Cu}(0.033)-\mathrm{Mn}(0.1$ or 0.5$)-\mathrm{Ce}$ $(0.1) / \mathrm{Al}_{2} \mathrm{O}_{3}$. The addition of $\mathrm{Mn}$ to $\mathrm{Cu}(0.033)-\mathrm{Ce}$ $(0.1) / \mathrm{Al}_{2} \mathrm{O}_{3}$ slightly improves $\mathrm{NO}_{x}$ reduction at low temperatures, but significantly decreases $\mathrm{NO}_{\mathrm{x}}$ conversion at high temperatures. Fig. 3(b) shows a large increment in $\mathrm{C}_{3} \mathrm{H}_{6}$ conversion caused by $\mathrm{Mn}$ addition. As discussed for Fig. 2, the addition of $\mathrm{Mn}$ to $\mathrm{Cu}-\mathrm{Ce} /$ $\mathrm{Al}_{2} \mathrm{O}_{3}$ effectively improves the $\mathrm{NO}$ oxidation, which is considered to be one of the main reasons for the increase in $\mathrm{NO}_{\mathrm{x}}$ conversion at low temperatures. The improved propene activation is the other factor. At high temperatures, the promotional effect of Mn additive on the oxidation of NO is limited by the thermodynamic equilibrium. Furthermore, the addition of $\mathrm{Mn}$ accelerates the wasteful consumption of $\mathrm{C}_{3} \mathrm{H}_{6}$ by $\mathrm{O}_{2}$ too much, and directly results in a decrease in $\mathrm{NO}_{\mathrm{x}}$ conversion. Kim et al. ${ }^{5)}$ reported a similar result, that the addition of $\mathrm{Mn}$ or La to a coppersupported aluminate catalyst had no positive effect on NO reduction with $\mathrm{C}_{3} \mathrm{H}_{6}$. They proposed that the Mn and $\mathrm{La}$ additives did not penetrate well into the alumina structure due to the low spinel formation rates of $\mathrm{Mn}$ and $\mathrm{La}$, and surface $\mathrm{La}$ and $\mathrm{Mn}$ accelerated the $\mathrm{O}_{2}+\mathrm{C}_{3} \mathrm{H}_{6}$ reaction.

Figure 4 shows the XRD patterns of different anodic alumina catalysts. The broad diffraction lines of low intensity at $2 \theta=37.6,39.4,45.9$ and 66.8 associated with the alumina support indicate the presence of crystalline $\gamma$-alumina. All samples exhibited the same pattern of diffraction peaks as the parent $\gamma$ alumina. This result demonstrates that the impregnation with $\mathrm{Cu}, \mathrm{Mn}$ and $\mathrm{Ce}$ does not destroy the original framework of the alumina support. In Figs. 4 (b), (c) and (d), there are no diffraction lines attrib-

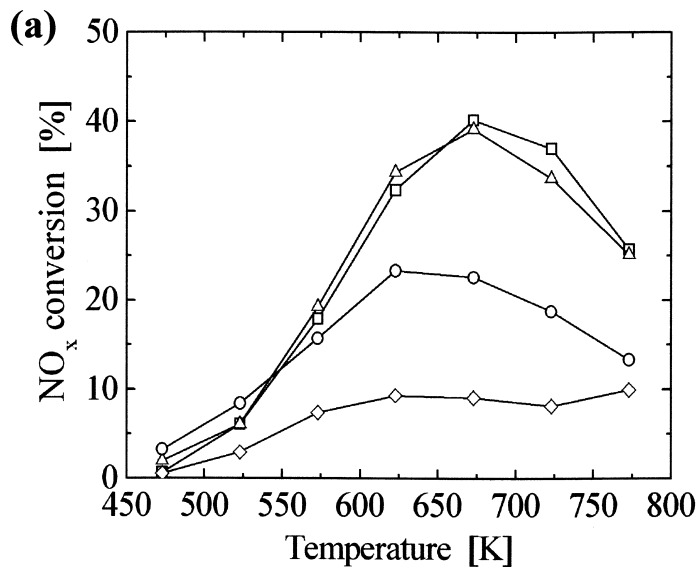

utable to crystalline bulk oxide phases of the metals supported. It is supposed that the relatively low metal loading ( $<4 \mathrm{wt} \%$, based on the weight of alumina film) makes the detection by wide-angle XRD difficult.

Figure 5 shows the results of the stability test in the presence or absence of $\mathrm{SO}_{2}(500 \mathrm{ppm})$ and $\mathrm{H}_{2} \mathrm{O}$ (10 vol\%) achieved over $\mathrm{Cu}(0.033)-\mathrm{Ce}(0.1) / \mathrm{Al}_{2} \mathrm{O}_{3}$ at $723 \mathrm{~K}$. $\mathrm{NO}_{\mathrm{x}}$ and $\mathrm{C}_{3} \mathrm{H}_{6}$ conversions are decreased when 10 vol\% $\mathrm{H}_{2} \mathrm{O}$ is present in the feedstream, due to the competitive adsorption of water vapor and reactants on active sites. This is almost reversible when $\mathrm{H}_{2} \mathrm{O}$ is switched off. The small difference remaining for $\mathrm{NO}_{\mathrm{x}}$ conversion is related to the effect of vapor on the alumina support, similar to the hydration of alumina. Inter-

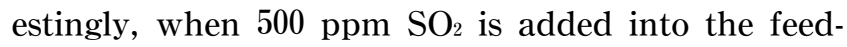
stream, a dramatic increase in $\mathrm{NO}_{\mathrm{x}}$ conversion (from $39 \%$ to $50 \%$ ) is observed, accompanied by an obvious increase in $\mathrm{CO}$ selectivity and a small drop in propene conversion. Furthermore, this promotional effect on

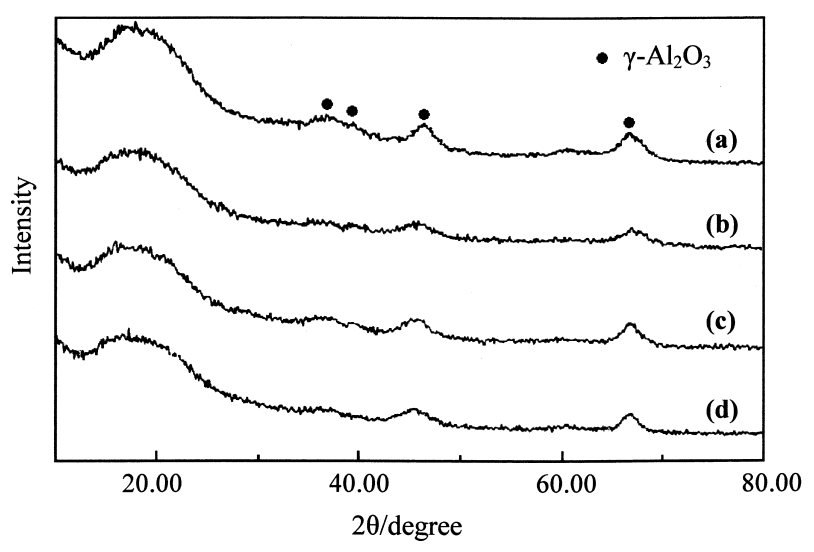

Fig. 4 X-ray diffraction patterns of different catalysts. (a) Alumina support ; (b) $\mathrm{Cu}(0.033)-\mathrm{Mn}(0$. 5) $-\mathrm{Ce}(0.1) / \mathrm{Al}_{2} \mathrm{O}_{3}$

(c) $\mathrm{Cu}(0.033)-\mathrm{Ce}(0.1) / \mathrm{Al}_{2} \mathrm{O}_{3} ;$ (d) $\mathrm{Mn}(0.5)-\mathrm{Ce}$ $(0.1) / \mathrm{Al}_{2} \mathrm{O}_{3}$

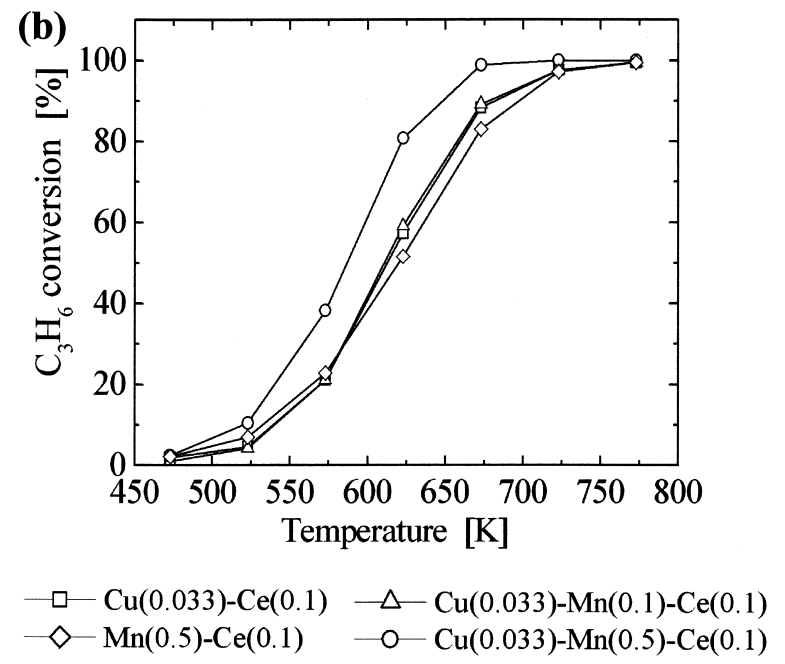

Fig. 3 Catalytic activities of $\mathrm{Cu}-\mathrm{Ce} / \mathrm{Al}_{2} \mathrm{O}_{3}, \mathrm{Mn}-\mathrm{Ce} / \mathrm{Al}_{2} \mathrm{O}_{3}$ and $\mathrm{Cu}-\mathrm{Mn}-\mathrm{Ce} / \mathrm{Al}_{2} \mathrm{O}_{3}$. (a) $\mathrm{NO}_{\mathrm{x}}$ Conversion, (b) $\mathrm{C}_{3} \mathrm{H}_{6}$ Conversion $\left(\mathrm{O}_{2} 15.0\right.$ vol\%, $\mathrm{C}_{3} \mathrm{H}_{6} 0.5$ vol\%, NO 1000 ppm) 


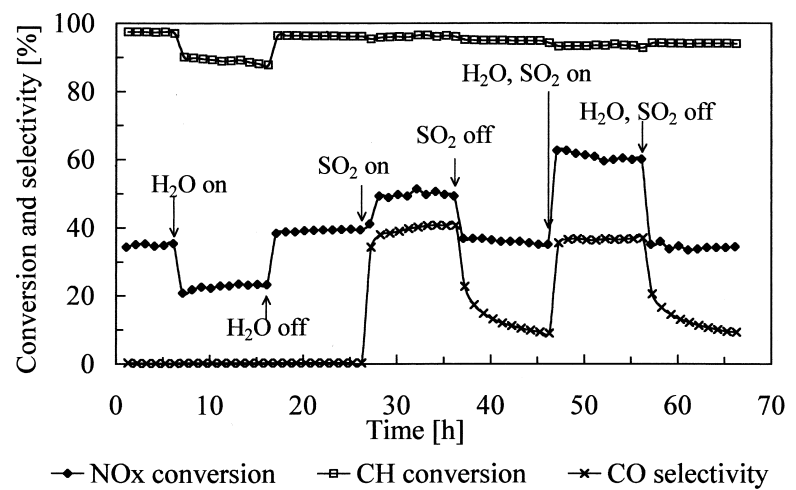

Fig. 5 Effect of $\mathrm{H}_{2} \mathrm{O}$ and $\mathrm{SO}_{2}$ over $\mathrm{Cu}(0.033)-\mathrm{Ce}(0.1) /$ $\mathrm{Al}_{2} \mathrm{O}_{3}$ upon step-feed and shut-off or $\mathrm{SO}_{2}$ and $\mathrm{H}_{2} \mathrm{O}$ at $723 \mathrm{~K}$.

( $\mathrm{O}_{2} 15.0 \mathrm{vol} \%, \mathrm{C}_{3} \mathrm{H}_{6} 0.5 \mathrm{vol} \%$, NO $1000 \mathrm{ppm}$, $\mathrm{SO}_{2} 0$ or $500 \mathrm{ppm}, \mathrm{H}_{2} \mathrm{O} 0$ or 10 vol\%)

$\mathrm{NO}_{x}$ reduction becomes more dramatic when $\mathrm{H}_{2} \mathrm{O}$ and $\mathrm{SO}_{2}$ are introduced into the feedstream simultaneously. The presence of $\mathrm{SO}_{2}$ is considered to impede the wasteful consumption of $\mathrm{C}_{3} \mathrm{H}_{6}$ by $\mathrm{O}_{2}$, and make more $\mathrm{C}_{3} \mathrm{H}_{6}$ available for the $\mathrm{NO}_{x}$ reduction. However, it should be noted that excess $\mathrm{SO}_{2}$ might also impede propene activation. The addition of vapor is supposed to dilute $\mathrm{SO}_{2}$ and lessen the $\mathrm{SO}_{2}$ inhibition of propene activation. During aging in $\mathrm{H}_{2} \mathrm{O}$ and $\mathrm{SO}_{2}$ for $10 \mathrm{~h}$, no significant decay in the de- $\mathrm{NO}_{\mathrm{x}}$ activity was observed. We do not yet have sufficient knowledge to explain the promotional effect of $\mathrm{SO}_{2}$ on $\mathrm{NO}_{\mathrm{x}}$ reduction over the $\mathrm{Cu}-\mathrm{Ce} / \mathrm{Al}_{2} \mathrm{O}_{3}$ alumina catalyst. The formation of sulfate-like species may be one possibility. A more detailedstudy is now in progress.

According to the aforementioned results, the $\mathrm{Cu}-\mathrm{Ce} /$ $\mathrm{Al}_{2} \mathrm{O}_{3}$ anodic alumina catalyst shows favorable de- $\mathrm{NO}_{x}$ activity even in the presence of excess $\mathrm{H}_{2} \mathrm{O}$ and $\mathrm{SO}_{2}$. This is very promising for further development of the $\mathrm{Cu}-\mathrm{Ce} / \mathrm{Al}_{2} \mathrm{O}_{3}$ catalyst as a denitration catalyst for the SCR-HC of $\mathrm{NO}_{\mathrm{x}}$ in diesel engine exhaust. With regard to the application of the $\mathrm{Cu}-\mathrm{Ce} / \mathrm{Al}_{2} \mathrm{O}_{3}$ catalyst for $\mathrm{NO}_{\mathrm{x}}$ removal, the coexistence of toxic particulate matter (PM) originating from incomplete combustion in diesel engine exhaust cannot be neglected. In our study, in cooperation with Lead Industry Company Ltd., we designed a novel catalytic purification system for the simultaneous removal of $\mathrm{NO}_{\mathrm{x}}$ and $\mathrm{PM}$ (shown in Fig. 6). Controlled amounts of air and fuel are introduced into the PM combustion chamber to burn off PM over a Pt-supported anodic alumina catalyst ${ }^{21}$. The residual fuel in the outlet stream is used as reducing agent to add into the $\mathrm{NO}_{\mathrm{x}}$ purification chamber for $\mathrm{NO}_{x}$ removal over the $\mathrm{Cu}-\mathrm{Ce} / \mathrm{Al}_{2} \mathrm{O}_{3}$ alumina catalyst. Temperature control of the $\mathrm{NO}_{\mathrm{x}}$ purification chamber can prevent a mismatch between the temperature of engine exhaust and the optimal operating window of the denitration catalyst. Moreover, the availability of appropriate concentrations of reductants by the adjustment of the air/fuel ratio is considered the most valuable aspect. However, it is impractical to direct-

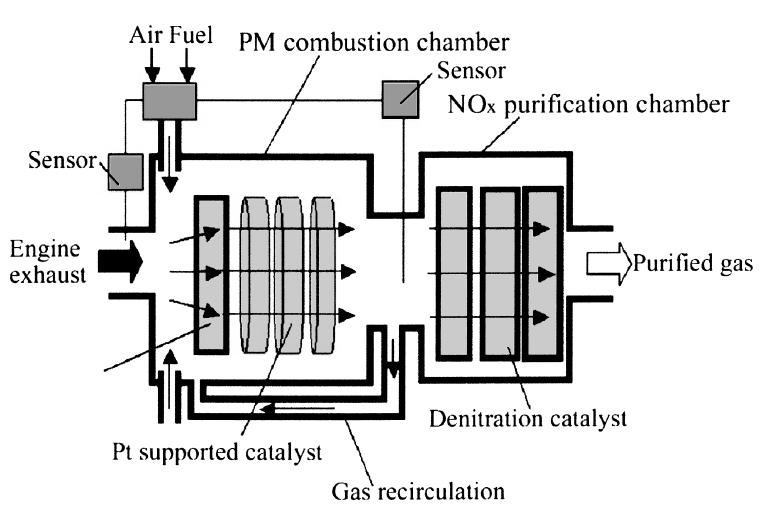

Fig. 6 Catalytic purification reactor for removal of PM and $\mathrm{NO}_{\mathrm{x}}$.

ly introduce propene for the feed of the PM combustion chamber for removal of $\mathrm{PM}$ and $\mathrm{NO}_{\mathrm{x}}$. Research on utilizing fuel oil (e.g. kerosene) instead of propene is now in progress. In addition, due to the low melting point of the aluminum interlayer, overheating may result in the destruction of the aluminum-containing composites. Hence, the thermal stability of the anodic alumina catalyst must be further improved. Recently, a clad aluminum material, in which an $\mathrm{Fe} / \mathrm{Cr}$ alloy interlayer is clad by an aluminum film of $40 \mu \mathrm{m}$, has been adopted as a base material to prepare a clad anodic alumina catalyst. Research shows that the clad alumina catalyst is unchanged at a higher temperature (until ca. $1073 \mathrm{~K}$ ). A more detailed study is now in progress.

\section{Conclusions}

A series of $\mathrm{Cu}-\mathrm{Mn}-\mathrm{Ce} / \mathrm{Al}_{2} \mathrm{O}_{3}$ anodic alumina catalysts synthesized using the multi-impregnation method were employed to investigate the selective reduction of $\mathrm{NO}$ with $\mathrm{C}_{3} \mathrm{H}_{6}$ in the presence of excess oxygen.

The presence of $\mathrm{Cu}$ additive greatly promoted the low-temperature $\mathrm{NO}_{\mathrm{x}}$ removal activity. A moderate loading of copper gave the most promising $\mathrm{NO}_{\mathrm{x}}$ conversion. In contrast, no promotional effect on lowtemperature de- $\mathrm{NO}_{\mathrm{x}}$ activity was found when $\mathrm{Mn}$ was added to the alumina support. Although the Mnsupported catalyst exhibited a higher activity for the oxidation of $\mathrm{NO}$ to $\mathrm{NO}_{2}$, the addition of $\mathrm{Mn}$ to the $\mathrm{Cu}-\mathrm{Ce} / \mathrm{Al}_{2} \mathrm{O}_{3}$ catalyst had no positive effect on $\mathrm{NO}_{x}$ reduction, due to the wasteful consumption of propene. The de- $\mathrm{NO}_{x}$ activity of the $\mathrm{Cu}-\mathrm{Ce} / \mathrm{Al}_{2} \mathrm{O}_{3}$ catalyst was maintained at a relatively high level, even in the presence of excess $\mathrm{SO}_{2}(500 \mathrm{ppm})$ and $\mathrm{H}_{2} \mathrm{O}(10$ vol\%). Furthermore, the presence of $\mathrm{SO}_{2}$ was observed to dramatically promote $\mathrm{NO}_{\mathrm{x}}$ reduction at $723 \mathrm{~K}$.

(Received November 5,2003; Accepted February 18,2004)

\section{References}

1) M. Iwamoto, H. Yahiro, K. Tanda, N. Mizuno, Y. Mine and S. Kagawa ; J. Phys. Chem., 95, 3727 (1991)

2 ) V. Pitchon and A. Fritz ; Appl. Catal. B : Environmental, 13, 1 (1997) 
3 ) D. Michel, F. Jennifer and F. Robert ; Appl. catal. A : General, 188, 219 (1999)

4) P. Carniti, A. Gervasini, V. Modica and N. Ravasio ; Appl. Catal. B : Environmental, 28, 175 (2000)

5 ) T. W. Kim, M. Kang, H. L. Koh and K. L. Kim ; Journal of Chemical Engineering of Japan, 34, 221 (2001)

$6)$ N. A. S. Amin, E. F. Tan and Z. A. Manan ; Appl. Catal. B : Environmental, 43, 57 (2003)

7 ) J. Shibata, K. Shimizu, A. Satsuma and T. Hattori ; Appl. Catal. B : Environmental, 37, 197 (2002)

8 ) H. Hamada, Y. Kintaichi, M. Sasaki, T. Ito and M. Tabata ; Appl. Catal., 70, L 15 (1991)

9 ) H. Hamada, Y. Kintaichi, M. Sasaki, T. Ito and M. Tabata ; Appl. Catal., 75, L 1 (1991)

10) H. Hamada ; Catal. Today, 22, 21 (1994)

11) C. Yokoyama and M. Misono ; Journal of Catalysis, 150, 9 (1994)

12) Y. Nishizaka and M. Misono ; Chem. Lett, 2237 (1994)
13) Y. Guo, M. Sakurai, H. Kameyama, A. Matsuyama and Y.Kudoh; Journal of Chemical Engineering of Japan, 36, 1470 (2003)

14) H. Kameyama ; Suiso Enerugi Shisutemu, 20, 16 (1995)

15) K. Murata and H. Kameyama ; Hyomen Gijutsu, 47, 173 (1996)

16) H. Kameyama ; Hyomen Gijutsu, 48, 994 (1997)

17) A. Iglesias-Juez, A. Martínez-Arias and M. FernándezGarcía ; Journal of Catalysis, 221, 148 (2004)

18) G. Z. Lu, X. Y. Wang, S. L. Wu and R. Ren ; Journal of East China University of Science and Technology, 21, 363 (1995)

19) K. Shimizu, H. Maeshima, A. Satsuma and T. Hattori ; Appl. Catal. B : Environmental, 18, 163 (1998)

20) F. C. Meunier and J. R. H. Ross ; Appl. Catal. B : Environmental, 24, 23 (2000)

21) Y. Kudoh ; US Pat. 6, 302, 935 (2001) 